\title{
THE VIEWS OF SEVERAL INDONESIAN REFORMED THEOLOGIANS REGARDING ECUMENICITY
}

\author{
Agustinus M. L. Batlajery \\ Universitas Kristen Indonesia Maluku
}

\begin{abstract}
ABSTRAK: Berdasarkan riset-riset sejarah mengenai gerakan ekumenikal di Indonesia, dapat ditemukan bahwa pembentukan Dewan Gereja Indonesia (DGI) yang kemudian berubah namanya menjadi Persekutuan Gereja-gereja di Indonesia (PGI) tidak dapat dipisahkan dari peran pemimpin gereja Calvinis atau Reformed pada waktu itu. Di dalam mendiskusikan mengenai stimulus dan urgensinya kesatuan gereja-gereja di Indonesia, kita dapat melihat beberapa tokoh Reformed sangatlah penting. Pendapat-pendapat mereka dipengaruhi oleh pemikiran Calvinis yang menjadi ciri gereja mereka. Artikel ini mencoba untuk memaparkan pandangan beberapa teolog Reformed Indonesia sebelum dan sesudah pembentukan DGI/PGI mengenai keekumenisan. Oleh karena itu kita dapat berkata bahwa pemikiran Calvinis telah memainkan peran yang sangat berharga di dalam gerakan ekumenikal di Indonesia.
\end{abstract}

KATA-KATA KUNCI: gerakan ekumene, kesatuan gereja, teolog reformed, calvinis.

ABSTRACT: Based on historical researches concerning ecumenical movement in Indonesia, it could be found that the formation of the Council of Churches in Indonesia (DGI) which later changed its name to the Communion of Churches in Indonesia (PGI) can not be separated from the role of Calvinist or Reformed church leaders and theologians at the time. In discussing about stimulus and urgency for unity among various churches in Indonesia, we can see that the views of several Reformed figures was very significant. Their opinions were effected by Calvinist thinking that chracterized their churches. This article is trying to describe the views of 
several Indonesian Reformed theologians before and after the formation of DGI/PGI regarding ecumenicity. Therefore we can say that Calvinist thinking has played very valuable role in the ecumenical movement in Indonesia.

KEYWORDS: ecumenicity, ecumenical movement, church unity, Indonesian Reformed Theologians, Calvinist thinking.

\section{Introduction}

In speaking about ecumenicity in Indonesia we must refer to the way in which the ideas of church unity were developed. Based on history, it explicitly mentioned several Reformed figures involved in shaping the Council of Churches in Indonesia and those who put forth their ideas at ecumenical meetings such as the General Assembly of the Council of Churches in Indonesia. This article will discuss how Calvinist theologians viewed church unity. Their ideas helped to advance the ecumenical movement in Indonesia. There are many, but a few of the outstanding ones include: J. Leimena, W.J. Rumambi, R. Soedarmo, H. Hadiwijono, J.L.Ch. Abineno, Agustina Lumentut, and Eka Darmaputera. In choosing these particular names, the following considerations were taken into account: membership in Calvinist-based churches; regional representation; activeness in the ecumenical movement both with ideas as well as involvement in the organizational structure of the Council/Communion of Churches; and gender representation. Broadly speaking, Indonesian churches can be divided into the Eastern region and the Western region. People like Leimena, Rumambi, Abineno and Lumentut are seen as representing the Eastern region, whereas Soedarmo, Hadiwijono and Eka Darmaputera are seen as representing the Western region. With the exception of Harun Hadiwijono, all have held positions in the Council of Churches in Indonesia 
or the Communion of Churches in Indonesia. Agustina Lumentut was the first woman to hold an office in the Communion of Churches in Indonesia.

But before we continue by describing their views it might be better to see Calvin's opinion about unity of the church.

\section{Church Unity According to Calvin}

To procure Calvin's views on one of his basic teachings, we must examine every kind of work that came from his own hand. These works are numerous, from his Institutes, bible commentaries, letters, tracts and catechisms to his sermons. Scholars now accept the fact that we cannot underestimate any of his writings if we want to study Calvin's thinking on any particular issue. ${ }^{1}$ But because of space is limit, we will focussing this study on the Institutes alone. The reason is that Calvin was very well known by this work and based on it he everywhere developted his thinking in the other writings.

In the 1536 Institute, ${ }^{2}$ Calvin's view of church unity is expressed in article 2 entitled "Faith: Containing an Explanation of the Creed (Called Apostolic)." There his teachings on church unity are incorporated into his teachings about the church. He stressed the following points about church unity:

1. He emphasized the unity of the church when he commenced his explanation with "First, we believe the holy catholic church". ${ }^{3}$ The emphasis on unity is apparent in the use of the word "catholic" (catholica). The Church is catholic or universal (ecclesia catholica). In essence this means that the church is all encompassing, all inclusive, and is not limited by

\footnotetext{
1 David Steinmetz, Calvin in Context (New York: Oxford University Press, 1995), vii; cf. W. de Greef, The Writings of John Calvin An Introductory Guide, (Grand Rapids: Baker Book House Company, 1993), 7-11; J.K.S. Reid, Calvin Theological Treatises, (Philadelphia: Westminster Press, MCMLIV), 13; Basil Hall, John Calvin Humanist $\mathcal{E}$ Theologian, (London: Wimmans \& Sons LTD, 1936), 5-6.

2 The writer has used the latest printing of the 1536 Institutes by Ford Lewis Battles in 1995 while referring to Calvini Opera Selecta 1926 hereafter abbreviated as 1536 Inst.and OS.

31536 Inst., 58; Primus credimus sanctam ecclesiam catholicam", OS I, 86.
} 
space and time. It exists in all times and in all places. In this sense, catholicity can be understood to mean that the church is one. ${ }^{4}$ In other words, the church is essentially one because of its catholicity. Calvin understood catholicity as unity.

2. If the church is catholic or universal, which in this case means one, then it is impossible to divide it into two or three churches. There is only one church on earth, one body of Christ of which Christ is the head. In Him all of the chosen are united and grow together into one body. In Him as the head, all of the chosen people are united as members of one body. Calvin said: "Now this society is catholic, that is, universal because there could not be two or three churches. But all God's elect are so united and conjoined in Christ (cf.Eph.1: 22-23) that, as they are dependent upon one head, they all grow together (cf.Eph.4:16) like the limbs of one body (Rom.12:5; 1 Cor.10:17; 12:12, 27). "5

3. The oneness of the church according to Calvin is based in Christ. It is Christ who is the center and foundation of the church. Therefore it is Christ who unifies the church. It is stated in that way because Christ is the head who leads and rules over the church, as is explained in the following sentences: ".... Of it, Christ Our Lord is Leader and Ruler and, as it were, Head of one body" ..... But all God's elect are so united and conjoined in Christ, .... are dependent on one Head ....."6 In other words, unity in Christ had become extremely important for Calvin. Where there is Christ, so also there is the church. From this we can understand why Calvin emphasized two living signs or symbols of the church: preaching

4 Cf. I.John Hesselink, "Calvinus Oicumeniccus Calvin's Vision on the Unity of the Church," in Reformed Review Volume 44 No.2 (1990): 99-100. See also I.John Hesselink, On Being Reformed: Distinctives, Characteristics, and Common Misunderstanding, (Grand Rapids: Eerdmans Printing Company, 1988), 87.

51536 Inst., 58; OS I, 86: "Haec autem societas catholica est, universalis, quia non duas aut tres invenire liceat, verum electi Dei sic Omnes in Christo uniuntur ac coadunantur ut, .....

6 Idem. 
of the Word and administration of sacraments. He mentioned these because in his view Christ is present in both of them. So, for Calvin the emphasis is put on Christ as the head the only one head of the church which is his body. The head of the church is not the pope who rules in Rome. Therefore it can be said that Calvin's thinking about the church from the very beginning was, in essence, "Christ-centered". ${ }^{7}$

4. Following his affirmation that the church is catholic, Calvin explained the content and scope of the catholic church as follows:

... that is the whole number of the elect, whether angels or men (Eph.1:9-10; Col.1:16), of men, whether dead or still living; of the living in whatever lands they live, or whatever among the nations, they have been scattered... ${ }^{8}$

The church consists of God's elect, ${ }^{9}$ whether angels or men, the living and the dead, who live in different lands and nations. They are united in one church, one community and one congregation of God. What Calvin wanted to emphasize here was the invisible dimension of the church. The church is not only real and visible in human eyes, but also invisible. The visible church is not always the rightful church. That is why he said that the elect, the angels and the dead are included in the sense of church. Calvin emphasized that there is no limitation of space and time for those which are called the church. In every place and nation the church can be found. The church is unlimited and not enclosed within the territory of the pope's authority in Rome. The church could expand and penetrate the frontier of the empire of Rome's territory. They remained the called as the catholic church with Christ as the Head.

5. It is interesting to see Calvin's further explanation of the election. For him, God's elect as the church, were chosen based simply on God's grace and kindness, and such election did not just happen but was done before

\footnotetext{
7 Willem Balke, Calvin and the Anabaptist Radicals, (Grand Rapids: Eerdmans Publishing Company, 1981), 49; Wilhelm Niesel, The Theology of John Calvin, (London: Lutterworth Press, 1956), 247.

81536 Inst., 58; OS I, 86.

9 OS I, 86: "universum electorum numerum".
} 
He created the universe. The purpose of the election was to ensure that all of God's people could be gathered into his kingdom.

... according as, through divine goodness, they have been chosen in him before the foundation of the world (Eph.1:4), in order that all might be gathered into God's kingdom. ${ }^{10}$

The emphasis was given to: 1) God's freedom, meaning that the election which happened before the foundation of the world was simply done with God's blessing. God's elect were not just determined, but far before their time. Therefore, the principle of the establishment of the church was God's justification, and the election was behind it. By quoting Romans 8:30, he said: "Those whom he has chosen from men he calls; those whom he has called, he justifies; those whom he has justifies, he glorifies". ${ }^{11}$ Thus for the first time, Calvin spoke about election and predestination. 2) The understanding of the church as the kingdom of God. However, the kingdom of God here included the invisible church. The kingdom of God was not just manifested on earth simply in a visible church.

6. The unity of the church was also the unity in faith, hope and love. Moreover, the unity of the church was created by the same Spirit. In the same Spirit they were called to inherit eternal life. It was said that:

These are made truly one who live together in one faith, hope and love, and in the same Spirit of God, called to inheritance of eternal life. ${ }^{12}$

7. Indeed the church is essentially the one and only. Such oneness was clearly established in Christ as the principal and Head. Therefore, from the time of the church's establishment with Christ as the Head, church unity was already in existence. We could say in this case that the unity of the church is a gift from God. But Calvin clearly recognized that in reality

101536 Inst., 58; OS I, 86.

11 Ibid.

12 Ibid. 
the church tends to separate because of place or location and doctrinal issues. Aside from affirming unity as the essential feature of the church, in this way he also asserted that it was our duty to exert ourselves to make it become more evident. He described it in the following statement:

They also grow together into one body, being joined and knit together as are the limbs of one body. ${ }^{13}$

8. It was further clarified that the church, which is essentially one, is sacred. It is holy because it was well maintained by God, was adopted to be a part of his body and was sanctified by Him. The holiness of the church has to do with God and his work, not with the people who rule the church:

It is also holy because as many as have been chosen by God's eternal providence to be adopted as members of the church, all of these are made holy by the Lord. ${ }^{14}$

9. Looking at Calvin's thought concerning church unity, the manifestation of the church unity for Calvin could be seen in the celebration of Holy Communion. He believed that to celebrate the sacraments meant praying whole-heartedly so that we are filled with love, peace and unity. Since Christ has only one body in which we are called to partake, it is necessary for all of us to be joined through participation in Holy Communion. This oneness is symbolized by one bread with many kernels of grain, expressing a mutual bond. Calvin reflected on it with these words:

... Because Christ has only one body, of it he makes us all partakers, it is necessary that all of us be made one body by such participation. ...in this way we should be joined and bound together by such great agreement of hearts that no sort of disagreement or division may intrude. ${ }^{15}$

13 Ibid.

14 Ibid.

15 Balke, Calvin and the Anabaptist Radicals, 56. 
Calvin gave the impression that he was opposed to schism and division. He viewed the sacraments, particularly Holy Communion, as a way of evading these matters. It is understandable from this why Calvin wanted the Holy Communion to be celebrated frequently. ${ }^{16}$

What was said by Calvin in the first edition of the Institutes was developed further in this later editions. Several assertions stand out. ${ }^{17}$

10. If in the first edition, he views the church more as "the mystical body of Christ", in this second edition he puts forward "the visible church", that is, the visible dimension of the church. Here for the first time he uses the term "ecclesia visibilis". According to Calvin, the church has two dimensions, the invisible dimension and the visible dimension. So the unity that he spoke of will now be applied to the visible church. The visible church consequently must manifest its unity.

11. Indeed, the catholic and universal church is a gathering of chosen people who come from various nations and are scattered in different places. Still, they agree on the truth of the gospel and are bound to one another by the same faith. This shared truth and faith is what unites them. Church unity thus lies in holding and agreeing upon one true doctrine or, in other words, the unity of fundamental beliefs. ${ }^{18}$

12. In line with Cyprian, Calvin justifies the view that it is only through the church that salvation can be attained. "There is no salvation outside the church," he said, borrowing the words of Cyprian and applying them to the visible church. With this quote Calvin's intent was to emphasize that breaking away from the church truly meant leaving the salvation

\footnotetext{
16 J. L. Ch. Abineno, Johanes Calvin Pembangunan Jemaat Tata Gereja dan Jabatan Gerejawi (Jakarta: BPKGM, 1992), 21.

17 The text of the Institutes used is John T. McNeill, (ed.), Institutes of Christian Religion, trans. F.L. Battles, Philadelphia, 1960. Because this Institute already consists of four books, the quotes were taken by referring to these books. Hereafter the abbreviations Inst.I, II, III, IV are used followed by chapter, point and code. The codes are ' $b$ ' for the 1539 edition; ' $c$ ' for 1543 edition. 18 Inst. IV. i. 9 (b).
} 
that God had bestowed on us. Therefore, it was necessary for them to join together and remain in the church. So by citing Cyprian and applying it to the visible church, he wanted to emphasize the need to protect their unity or oneness. According to Balke, Calvin heavily underscores the necessity of maintaining the unity of the church. He takes over Cyprian's adage 'there is no salvation outside the church' and applies this statement to the visible church". ${ }^{19}$

The afore-mentioned intent is visible in the depiction he used to describe the visible church, that is, the church as "the mother of all believers". As a mother who carries, gives birth, raises, and offers life, it is not appropriate to break away from her because she is the only one who can grant salvation. ${ }^{20}$ By this, he intended once again, to assert the importance for anyone to become a member of the church and not to become estranged. According to Calvin, the church is the mother of believers, mother of all of us, and Christ's bride.

13. In accordance with this, by quoting Augustine he clarified that there was a difference between I believe in the Church and I believe the church. Since the church was not the subject of our faith but only the object, the correct expression is I believe the church. ${ }^{21}$ The church is the way of salvation which always places itself under God's authority. The subject of our faith is God. Therefore, to God we should say I believe in God, not in the church. To believe the church means to be convinced that we are members and that our salvation is firm; it relates to Christ's firmness which does not allow the believers to be taken away from Him, torn apart. He is convinced that the truth will stand firm for us as long as we stay in the church's womb. To believe the church means to partake in it. Consequently, the church and its unity must be consistently maintained. ${ }^{22}$

19 Balke, Calvin and the Anabaptist Radicals, 112

20 Inst. IV. i. 4 (b)

21 Inst. IV. i. 2 (b)

22 Inst. IV. i. 3 (b) 
14. Calvin said:

How we are to judge the church visible, which falls within our knowledge, is, I believe, already evident from the above discussion... Wherever we see the word of God purely preached and heard, and the sacraments administrated according to Christ's institutions, there, is not to be doubted, a church of God exists (cf. Eph. 2:20). ${ }^{23}$

Calvin consistently regards the preaching of the Word and the administration of the sacraments according to Christ's institution to be the signs which could identify and unite the church at the same time. ${ }^{24}$ Therefore he further mentioned that in this way we preserve for the universal church its unity, which devilish spirits have always tried to sunder.

15. Since Calvin was remarkably serious and consistent with reference to the unity of the church, any tendency toward separatism was rejected. As he stated, "For the Lord esteems the communion of his church so highly that be counts as a traitor and apostate from Christianity anyone who arogantly leaves any Christian society, provided it cherishes the true ministry of Word and sacramants". ${ }^{25}$ Separatism according to him is a satanic work. "For there is nothing that Satan plots more than to remove and do away with one or both of these. Sometimes he tries by heaping contempt upon them to drag us away from the church in open rebellion," he said. ${ }^{26}$

He further stressed that having Christ as the head is an absolute requirement for oneness. He described this with an illustration that came from Cyprian to explain church unity which is Christ-centered. ${ }^{27}$ Hence, we cannot separate ourselves from the visible church.

23 Inst. IV. i. 7 (b); Inst. IV. i. 9 (b)

24 Cf. Point 3 mentioned above

25 Inst. IV. i. $10(b)$

26 Inst. IV. i. 11 (b)

27 Inst. IV. ii. 6 (c) 
Maintaining community with the visible church is a command. This he stressed with the words:

Just as we must believe, therefore, that the former church, invisible to us, is visible to the eyes of God alone, so we are commended to reserve and keep communion with the latter, which is called 'church' is respect to men..$^{28}$

Furthermore, we see the views of several Reformed theologians regarding ecumenicity

\section{J. Leimena}

Johannes Leimena (1905-1977) came from Ambon. It could be said that, like his parents, he inherited Calvinist Christianity which was brought to Ambon. He was a member of the Protestant Church of Western Indonesia in Jakarta. This is another church of Calvinist background which, along with, among others, the Protestant Church of the Moluccas before it, belonged to the Protestant Church of Indonesia (GPI). After graduating from STOVIA (School Tot Opleiding Van Inlandsche Artsen (School for the Training of Indigenous Physicians), Leimena worked as a medical doctor in Bandung for eleven years from 1930 on. He received his doctor's degree in the health sciences in 1939. He was very actively involved in the struggle for Indonesian independence, both visibly and in the underground movement. After independence had been proclaimed, he held several government posts beginning with minister and vice-minister of finance, up to acting president. He was often entrusted to represent Indonesia in international negotiations. He can therefore be considered one of Indonesia's national figures. ${ }^{29}$ But Leimena was also a lay church leader. He was one of the founders of the

\footnotetext{
28 Inst. IV. i. 7 (c)

29 His complete curriculum vitae can be read in J. Verkuyl, Gedenken en Verwachten, (Kampen: 1983), 193-201. See also R.Z. Leirissa, Kewarganegaraan Yang Bertanggung Jawab, (Jakarta: BPK Gunung Mulia, 1980), 1-103; A.G. Hoekema, Berpikir dalam Keseimbangan yang Dinamis, (transl.), (Jakarta: BPK Gunung Mulia, 1997), 139.
} 
Christen Studenten Vereniging in Java, a coordinating institution for Christian student associations from various churches which gave rise to the Council of Churches in Indonesia. On several occasions he and his colleagues participated in international ecumenical conferences such as the one in 1938 in Tambaran. ${ }^{30}$ In the board of the DGI he once served as a vice-chairman.

Leimena poured out his ideas in various writings that revolved around two topics nationalism, which involved bringing the people together, and church unity. These two concerns often seemed to be closely linked in his thinking. A.G. Hoekema noted that Leimena's thinking was influenced by meeting with people like C.L.van Doorn, Hendrik Kraemer and W.A. Visser't Hooft. Through them, the need for harmony and oneness became very apparent to Leimena. For him, the motto "That they may be one" (Ut omnes unum sint) taken from John 17:22 was not only the task of the nation but a special task for the church. ${ }^{31}$ Van Doorn was an agriculturalist and a member of the Reformed church. He was assigned to work with Christian youth, particularly in Batavia, by the Dutch Christian Student Association (Nederlandsche Christen Studenten Vereniging or NCSV). Meanwhile, Hendrik Kraemer was sent by the Dutch Bible Society (Nederlandsch Bijbel Genootschap, or NBG) to Java. W.A. Visser't Hooft was to be the first secretary of the World Council of Churches who became actively involved in the development of the Indonesian Churches after the conference in Tambaran in 1938. In Tambaran he met Leimena and friends. So, the Reformed heritage that influenced these three men had an effect on Leimena. In an article entitled, "De Zending en wij" (Mission and Ourself), Leimena wrote:

30 Hoekema, Berpikir dalam Keseimbangan,139; cf. Chr. de Jonge, Menuju Keesaan Gereja, (Jakarta: BPK Gunung Mulia, 1990), 15.

31 Hoekema, Berpikir dalam Keseimbangan, 141. 
The job of the church is to knock down the walls of misunderstanding between ethnic groups here, between Europeans, Indonesians, and Chinese, if the church really wants to fulfill Christ's command, that they be one. ${ }^{32}$

In another article 33 , he declared that the church must work together for the renewal of society. Before independence in 1945, renewal was focused on the journey to Indonesian sovereignty. After independence, it was focused on harmony within that young country. The contribution of the church in this aspect of renewal began with individual renewal. The church would only be able to contribute if that renewal was visible within itself. In that regard several times he enthusiastically proposed the churches in Indonesia to unite.

Thus, for Leimena a conflict between nationalism and church unity should not be allowed even though the two differed. On one occasion he stressed that there was no other alternative for a Christian in Indonesia than to defend the unitary state of the Republic of Indonesia based on Pancasila. He even saw the goal of creating a fair and prosperous society as the task of a Christian. This is important in reference to the continental blocks that existed which could threaten world peace and brotherhood. He said:

Therefore Christians have no alternative but to defend the unitary state of the Republic of Indonesia based on Pancasila. The goal of forming a just and prosperous nation, based on Pancasila must also be the goal of Christians. In the world split into blocks, with its 'hot spots' in many continents, it is fitting that we as a people should participate in building up brotherhood among nations and peace in the world. ${ }^{34}$

But the Christian faith is above nationalism. According to Leimena, our relationship with the universal church must determine our relationship

32 J. Leimena, "De Zending en Wij", in CSV Blad 7/1, (Agustus 1940), 10-14.

33 J. Leimena, "De ontmoeting der rassen in the Kerk", in De Opwekker 87/12, 1941, 626-635.

34 J. Leimena, "The Task of Restoring Fellowship within the Church and the Indonesian Nation", in South East Asia Journal of Theology Vol. 9/3, (January 1968), 59. 
with our own people and with other peoples. ${ }^{35}$ For Leimena, the churches' self-understanding in Indonesia could not be separated from their understanding of the universal church. And this is important because the problem of the universality of the church was stressed by Calvin also as he described church unity. That means that there is plurality both in society and in the church. The church is pluralistic because it contains people of every race or nation. Yet that reality cannot create dissidence or conflict. On the other hand, plurality makes room for certain ethnic churches to forge ahead to a future vision. Leimena voiced this opinion when the need for a National Christian Council began to surface. For him, the future of the church in Indonesia was expressed as follows:

And so it shall be if God so wishes. We see in the future the establishment of one Indonesian church, one Chinese church and one Dutch church which together shall form one Protestant church in the Netherlands East Indies, as a Christian witness in the midst of a large and strong Muslim population. ${ }^{36}$

Leimena's stance gives the impression that his idea of church unity in Indonesia was some sort of federation of churches, something that had come up once as a question about the shape and content of church unity in Indonesia. However, this type of unity was not discussed further after that. He was very aware that the churches in Indonesia were ethnic and traditional churches that followed their home church. In this kind of situation, such churches could become narrow-minded and show little respect toward the ecumenical movement in Indonesia.

This ethnic basis, and to some extent traditionalism as well, can cause the churches to have a rather limited outlook, with the consequence that this can hinder ecumenical life in Indonesia. ${ }^{37}$

Because of that, churches needed to build up their self confidence and self-reliance in the realization that although they were separate as regional

35 Leimena, "De Ontmoeting der rassen in the Kerk", 626.

36 Leimena, "De Ontmoeting der rassen in the Kerk", 635.

37 Leimena, "The Task of Restoring Fellowship", 61 
churches, together they formed a church that was ecumenical. ${ }^{38}$ And an important element in the framework of church unity in Indonesia was this:

The efforts in the field of nation and character building at this time parallel our efforts in the ecumenical field in Indonesia. Efforts to strengthen the unity and union of the people parallel our efforts to unite the Christian churches in Indonesia. In this too Christian churches in seeking for unity are making a positive contribution to nation and character building in Indonesia. There is a possibility that God wishes to use our Churches, which are scattered throughout Indonesia in their efforts to form one united church, as an instrument to strengthen the union and unity of Indonesian people. Therefore our efforts in the field of the unity of the church responsibility for which has been given to the National Council of the Churches and which has received a good response from all the regional churches, should be continued so that, if this is God's will, in the future there will be in Indonesia one Christian church in our country. ${ }^{39}$

It is not surprising, then, that in addition to being actively involved in the struggle for nationhood; Leimena was also actively involved in the church ecumenical movement in Indonesia.

\section{W. J. Rumambi}

W. J. Rumambi (1916-1984) came from Minahasa. From 1940-1947 he served as a minister of the Evangelical Protestant Church in the Minahasa (GMIM). Like GPM, GPIB and GMIM at its inception also belonged to the Protestant Church in Indonesia (GPI). During World War II Rumambi worked in the Office of Religious Affairs in Manado under Japanese supervision. He was, among others, one of those who designed and framed the Council of Churches in Indonesia. When the Council of Churches in Indonesia was established in 1950, Rumambi became its first General Secretary, a position he held until 1954. Before that he had once been General Secretary of the Protestant Church of Indonesia (1948-1950). In

$\begin{array}{ll}38 & \text { Ibid., } 61 . \\ 39 & \text { Ibid., } 62 .\end{array}$ 
public life he once was a member of Indonesia's Constituent Assembly and he served as a minister in various cabinets from 1959-1966.40 Thus it could be said that he was not just a church figure but a national figure as well.

His views on church unity can be seen from his lectures, speeches, and sermons. In July 1948 the General Synod Assembly of the Protestant Church in Indonesia was held in Bogor. The assembly not only discussed the GPI matters but also the establishment of a coordinating institution with the Council of Churches in Indonesia. In that assembly, Rumambi was chosen as the General Secretary of the executive committee of the GPI. There he presented his ideas about the need to strive for church unity in Indonesia by forming a coordinating institution together. When he started this new position in 1948, he recounted in his speech discussions that had taken place at that Assembly in Bogor concerning the formation of the Council of Churches in Indonesia. He felt the article on ecumenism had become an important item on the agenda of that Assembly. F.L. Cooley quotes a statement by Rumambi in 1948 in which the importance of this issue is underscored:

At the General Assembly of the Synod in Bogor, lengthy deliberations were held on the chapter of relationship between... and oneness of the churches in Indonesia, the chapter on ecumenism. It can be said, that this chapter became the most important issue, as assembly reports indicated..$^{41}$

Here we see that the impetus, even the pressure, to create a coordinating ecumenical Council of Churches in Indonesia had come from Rumambi, a Calvinist from Minahasa, and it was also supported by the GPI. Since its inception, then, the GPI was one of the predominantly Calvinist churches that supported the drive for unity in Indonesia.

40 His complete curriculum vitae was written up by W.B. Sidjabat in the book Panggilan dan Tanggung Jawab Kita Dalam Pembangunan Bangsa, (Jakarta: BPK Gunung Mulia, 1985), 32-60; cf. H.G. Rorimpandey (ed.), W.J. Rumambi Setelah Fajar Merekah, (Jakarta: Sinar Harapan, 1994).

41 F. L Cooley, "Bagaimana Terbentuknya DGI" in: Peninjau II/4, 1975, 302. 
This GPI Assembly could be described as a proto-Ecumenical Church Assembly in Indonesia because among those present were delegates from the conference of churches centered in Yogyakarta, local church leaders from Medan (Sumatera), Dayaks from Kalimantan, and representatives from Chinese, East Javanese, and Pasundan churches.

Then, on 30 September 1949, Rumambi delivered a sermon at the $15^{\text {th }}$ anniversary celebration of GMIM in which he described the main purpose of that celebration. In it we can see his ecclesiastical insight which stressed church unity. We quote from this sermon:

Our primary purpose at this time is, together with GMIM, to praise God, the head of the Church, who has led GMIM for 15 years as an autonomous church. We do this because, as Christians together in Indonesia, we experience each other's joy. In a similar way, in times of difficulties, together we try to help churches which are facing difficulties. Are not the Christians in Indonesia and even in the whole world the expression of the one body of Christ with God himself as the head? Through this event tonight we hope that the unity of the churches in Indonesia has become strengthened; that the sense of fellowship and the Christian family has been affirmed. ${ }^{42}$

This ecclesiastical understanding is seen in the realization that Christians in Indonesia are the actualization of the body of Christ, where Christ himself is the head. Here Rumambi acknowledged that the church in Indonesia is part of the universal church, a view consistent with Calvin's concept of the church. The universal church is the body of Christ where Christ is the head. Church unity is found in Christ, the head of the church. Therefore Rumambi's premise that the GMIM's $15^{\text {th }}$ anniversary celebrations strengthened the unity of the churches and affirmed a sense of brotherhood and fellowship is Calvinistic.

The drive for church unity also needs to be seen from the viewpoint of evangelistic cooperation. Church divisions can become a stumbling block,

42 Rorimpandey (ed.), W.J. Rumambi Setelah Fajar Merekah, 350. 
preventing the world from believing the news the church proclaims. For that reason the church must not only witness but be united in that effort.

In carrying out evangelism, the churches in the world should cooperate or, more appropriately, attest to their oneness. The church must witness and also be united. Only if churches are united, can their message in this world be true appropriate. Can the world believe the church's message if the church itself is broken, rife with internal dissent and demonstrating a lack of mutual concern? ?3 $^{3}$

Seeing churches divided like this saddened Rumambi. He saw unity not just as something to be conscious of and to talk about but to put into practice in the life of the church.

With sadness we confess that there are divisions among the Lord's churches. These divisions are also visible in the field of evangelism. As much as possible we must overcome those divisions and form a more perfect union, realizing it in practice, in the life of the church. ${ }^{44}$

That church unity must be visible in the life of the church, we should note, is a Calvinist idea. Calvin stressed that church unity must be evident in a church that is visible. The visible church must manifest church unity. This was proposed in the 1539 Institutes.

Clearly Rumambi's contribution to church unity in Indonesia was not just ideological or theoretical. He donated his time and effort to the leadership of the ecumenical movement in Indonesia. Rumambi, S. Marantika and other colleagues were referred to by Hoekema as the proponents of ecumenism in Indonesia because of their involvement in the ecumenical movement. ${ }^{45}$

\section{R. Soedarmo}

43 Ibid., 254.

44 Ibid., 254.

45 Hoekema, Berpikir dalam Keseimbangan, 274-277. Marantika's ideas are not discussed separately here considering that they have already been dealt with in connection with Leimena and Rumambi who can be considered to represent the Calvinist church in the Eastern region of Indonesia. 
Raden Soedarmo (1914-1991) came from Java. As was mentioned above, his church was the Javanese Christian Church (GKJ), a Gereformeerd church in Central Java where he served as a pastor. He began theological studies at Vrije Universiteit (VU, Free University) in Amsterdam in 1937 and remained there throughout the war, finishing his doctorate in 1957 at the same university. From 1955-1978 he taught Dogmatics at the Jakarta Theological Seminary. He contributed his ideas on the church and church unity to the ecumenical movement in Indonesia, both through presentations at ecumenical assemblies and through his book Ikhtisar Dogmatika (1965) which he wrote as a textbook for theological seminaries.

In 1958 Soedarmo presented his ideas on unity at the Standing Committee meeting of the DGI. Undoubtedly Soedarmo's background played a role in shaping these ideas since he had come from a Calvinist church and had studied theology at a Calvinist university as well. It should be noted that he recognized the existence of many churches but felt that the number need not become a problem. "Even though there are many churches, church unity does not need to become an issue", he said. This idea was later presented in his above mentioned Ikhtisar Dogmatika. In it Soedarmo discussed the pluralistic church. ${ }^{46}$ The church has multiple forms, both in organization as well as in confessions of faith. Yet, unlike the Roman Catholic Church, different forms were not problematic since no church is absolutely correct and perfect. Here we see that Soedarmo's opinion is the same as the one expressed by Calvin in opposing the sectarian tendency of the Anabaptists who wanted to create an ideal church based on the New Testament. For Calvin this tendency meant a denial of New Testament testimony that the church was made up of sinners. For Soedarmo none of the churches were complete or ideal, but they were headed in that direction. In their eagerness to emphasize certain teachings, divergent views of the Holy

46 R. Soedarmo, Ikhtisar Dogmatika, (Jakarta: BPK Gunung Mulia, 1991), 213-215. First published in 1965. 
Scriptures had arisen and created differences. Those differences could be overcome as long as churches abided in love. For him, the dissention of the church is sinful. Soedarmo agreed with the Reformed churches which, he concluded, saw plurality in three matters: a) churches were not right or wrong, but all were correct to a greater or lesser degree. A holy universal church simply did not exist; b) therefore, churches should not slander one another but put love into action; c) there must continually be an effort to achieve unity, for a church of dissention was the result of sinfulness. ${ }^{47}$

Soedarmo then presented the reason for these ideas. 'The main thing is that churches are conscious of their oneness in Christ. This issue can only become contentious if they differ in their confessions of Jesus Christ, as if there were more than one Jesus Christ'. This view reminds us of Calvin's confirmation of unity in Christ, a unity centered in Christ, the head of the church. Christ is the basis and center of the church, and therefore it is Christ who unifies the church. As long as Christ is there, the church is there as well. For that reason Calvin considered unity to be based on the confession of Christ and not on uniformity in church organizational structure. This was also emphasized by Soedarmo. For him church unity was not synonymous with a command to seek a united worldwide church with one church order or one set of elders. Oneness as seen in the Roman Catholic Church could not become the objective. To achieve unity by gathering all groups together, regardless of a confession of Christ, would be deadly-appearing to be one on the outside but broken on the inside.

It is also of interest that Soedarmo emphasized unity in the same confession of Jesus Christ and saw this as the core problem for unity as well. Differences beyond that were considered secondary concerns that should be left alone, permitted, respected and valued. "Minor differences between one church and another must be left alone, permitted to exist, allowed as a subject for inquiry, and respected. As long as differences do not create the desire for secularism, they will not cause love to grow cold or relationships

$47 \quad$ Ibid., 214-215. 
to break up." 48 These ideas are in line with Calvin who saw the need for agreement in basic matters of the Christian faith and saw that unity was made visible in that way. Outside of those basic concerns, diversity could exist and did not need to be challenged. A Calvinist outlook like this is known as adiaphora.

If we read deeper ecclesiastically, the Calvinistic influence is obvious. Two matters clearly point this out: a) he analyzed the essence of the church from two perspectives, from that which is visible and from that which is invisible, and b) the visible identifying marks of a church include the faithful preaching of the Word of God, the right administration of the sacraments, and the existence of church strategy. ${ }^{49}$

As shown above, Soedarmo's ideas influenced the ecumenical movement in Indonesia and helped to develop the concept of unity in diversity.

\section{H. Hadiwijono}

Harun Hadiwijono (1915-1989)50, also came from Central Java and belonged to the same church as Soedarmo. For that reason his opinions were colored substantially by the Re-reformed tradition. After graduating from the Theological Seminary in Yogyakarta, he continued his studies at Vrije Universiteit (VU, Free University) Amsterdam, and received a doctor's degree from that institution in 1967. In addition to being a lecturer, he became President of Duta Wacana Theological Seminary long before that school had become a university. His views were expressed in several of his

48 In his article entitled "Mencari Bentuk-bentuk Keesaan Gereja di Indonesia", (mimeographed, source unknown) he supports this idea by saying that 'In the Bible there are matters which are central and matters which are not central'.

49 Ibid, 212-213, 215.

50 An extensive biography of Harun Hadiwijono can be found in the commemorating volume Yusri Panggabean et al. (ed), Penabur Benih Mazhab Teologi Menuju Manusia Baru, Jakarta, 2000. 
writings. Best known among them is the book Iman Kristen (Christian Faith), a handbook in dogmatics for theological seminaries in Indonesia.

In 1964 Hadiwijono wrote a brief article entitled, 'Kesatuan Geredja' (Church Unity). ${ }^{51}$ In it he describes unity as a spiritual problem, that is, unity in Christ. Church unity is experienced in the one body of Christ. This was the type of unity which we found in the article of the Apostle's Creed; "I believe in the holy catholic church, the communion of saints." In this confession he felt that Christians acknowledged one church which was holy and universal. This confession is consistent with the Bible and in accordance with the declaration of the church as the body of Christ. Hadiwijono explained:

In our confession of faith we state: I believe in the holy Catholic Church, the communion of saints. In this confession of faith we acknowledge that there is one holy and universal church. This confession is indeed in accordance with the Bible. Is the church not the body of Christ? (Ephesians 1:23). And there is only one Christ, and he only has one body. ${ }^{52}$

Note that the starting point for Hadiwijono was the confession of faith. When Calvin described his views on the church and church unity in the book Institutes, he too, used the confession of faith as his point of departure. Calvin also stressed that acknowledging the church as the body of Christ indicated in essence that God has only one church on earth.

Despite that, Hadiwijono did not reject the fact that there are many kinds of churches and that each of those churches regards itself as the true church. He felt that this conflicted with Lord's prayer in the gospel of John, "so that they may become one". That is why people of faith must work to achieve that unity. "Even though Jesus Christ prayed that his people would become one, and even though the Holy Spirit was poured out upon His congregation, Christians themselves must also work to achieve that unity." 53

\footnotetext{
51 H. Hadiwijono, "Kesatuan Geredja" in Penjadar II/12 Djuni 1956, 6-8.

52 Hadiwijono, "Kesatuan Gereja", 6; H. Hadiwijono, Inilah Sahadatku, (Jakarta: BPK Gunung Mulia, 1981), 136-140.

53 Hadiwojono, "Kesatuan Gereja", 7.
} 
According to Hadiwijono, church divisiveness is sinful and goes against the will of God. Soedarmo had voiced the same opinion. If sin is considered the act of the devil, we are reminded of Calvin's statement that separatism is the work of the devil.

Based on the discussion about Lord's Prayer in the Gospel of John and supported by the words of Paul in Ephesians 4:4-6, Hadiwijono argued that since all people of faith made up the body of Christ then they are also of one Lord and one faith. Again and again he stressed unity in the spiritual sense of the word, just as Calvin did.

Like Soedarmo, Hadiwijono acknowledged plurality and organizational diversity within the church, which was caused by different views of truth. Yet he saw that organizational unity might be implied as well in church unity. For him, however, organizational unity was not essential. The important thing was unity in faith, in the truth.

Nevertheless we are also aware that organizational unity is not absolutely essential for church unity. The church can be united as an organization yet in essence become divided. So first of all we must seek unity of faith, unity in truth. If this is achieved, it will be easy for organizational unity to follow. ${ }^{54}$

\section{Was This not Calvin's Observation as Well?}

It is interesting that Hadiwijono stated very emphatically in his book Iman Kristen that 'Divisiveness in a church is insulting to the Church.' 55 This he said in relation to the concept of the church as the body of Christ. The term body of Christ points to unity, unity in diversity. There may be role differences but all of it is carried out in one body, that is, in the body of Christ, the church. ${ }^{56}$ In discussing characteristics of the church, he stressed

\footnotetext{
54 Ibid., 7.

55 H. Hadiwijono, Iman Kristen, (Jakarta: BPK Gunung Mulia, 1982), 372.

56 Ibid., 371-375.
} 
that the orthodoxy of the Catholic Church was more or less the same as the unity found in Calvin's thinking.

It is impossible that the Church as a universal church would only be made up of like-minded people (Roman Catholic, Lutheran, Calvinist), closed to other groups, forming an elite nation or tribe, or tied to one specific period or culture. If in essence the Church is truly catholic, it must be universal because God's love is directed to the whole world. ${ }^{57}$

\section{J. L.Ch. Abineno}

J. L. Ch. Abineno (1917-1995) came from Timor. He belonged to the Evangelical Protestant Church in Timor (Gereja Masehi Injili Timor or GMIT) which, along with GMIM, GPM, and GPIB came together under the umbrella of the Protestant Church in Indonesia (GPI). After finishing his theological education at the Jakarta Theological Seminary, he returned to Timor and became the Chairman of the GMIT Synod from 1950-1953. He also served as the President of the Theological Seminary of Timor. Later he continued his doctoral studies at Utrecht University in the Netherlands and received his doctoral degree in Practical Theology in 1956 on a study about liturgical patterns in the Indonesian churches. Returning from the Netherlands, he lectured at the Jakarta Theological Seminary as a professor in Practical Theology. ${ }^{58}$ He served as general chairman of the Communion of Churches in Indonesia and thereafter as a member of its Advisory Board. He wrote more theological books in the Indonesian language more than any other theologian.

In 1983 Abineno presented his ideas about the church and church unity in a speech at the $49^{\text {th }}$ Anniversary of the Jakarta Theological Seminary in Jakarta. He described the ecclesiology of churches in Indonesia and pointed out that, in his perception, it emphasized three different aspects. There is first of all an ecclesiology that emphasized the church as an

\footnotetext{
57 Ibid., 379.

58 His curriculum vitae is to be found in Sularso Sopater (ed.), Apostole, Kumpulan Karangan dalam rangka Memperingati 70 Tahun Prof.Dr. J.L.Ch. Abineno, (Jakarta: BPK Gunung Mulia, 1987); See also "In Memoriam" in Berita Oikumene 222-223, Jan-Feb. 1995, 25-27.
} 
institution; secondly, an ecclesiology which emphasized the church as a spiritual union; and finally, ecclesiology that points to the church as the people of God sent into the world. ${ }^{59}$ These three aspects are found in Indonesian churches and are flourishing. The aspects which emphasize the institution relate to the teachings about the church as a godly institution for the salvation of humankind. The emphases on spiritual union relate back to Reformation teachings about the church which is visible and the church which is invisible. And the aspect which emphasizes the church being sent into the world relates to the ecclesiology which has been developed after the Second World War in Protestant circles in Europe and elsewhere. Based on his experiences in directing the Council of Churches in Indonesia, he noted that these three emphases were frequently contradictory. It was not surprising, therefore, that people were calling for a review of the church.

And it is these varying opinions that apparently are involved in causing church members within the Communion of Church member churches to suggest that we all once again carry out a review of the church. If we consider this seriously, as I think we should, then how should that review be conducted? ${ }^{60}$

In reference to that review, he suggested several points for further study, including the need for a new ecclesiology, the understanding of church unity, and the understanding of unity and truth.61 For the understanding of church unity, he analyzed the purpose of the prayer of Jesus in John 17. What was intended in this Bible verse, Abineno said, was not a 'mystical unity' or 'spiritual unity' that is invisible but 'unity as a visible reality that could be seen by each person'. In addition to unity (oneness), Abineno also discussed the understanding of 'the body of Christ' and Unio cum Christo. Once again he stressed that what was intended was

\footnotetext{
59 J. L. Ch.Abineno, Gereja dan Keesaan Gereja, (Jakarta: BPK Gunung Mulia, 1983), 2-10.

60 Ibid., 10-11.

61 Ibid., 11-16.
} 
not something mystical, something supernatural, or something that was beyond our world. Unio cum Christo always assumes concrete action; concrete obedience, concrete loyalty, concrete service. ${ }^{62}$

This belief is related to the understanding that the church is a visible reality, not something abstract but concrete. ${ }^{63}$ Abineno reminds us about Calvin who felt that church unity is not only suited for churches that are invisible but must also be visible in the life of the church. Indeed, according to Abineno, there is diversity in a church that is visible. This fact cannot be overlooked in the task of unification because the Bible emphasizes both. Therefore unity must be thought of within diversity, and so also must diversity be encompassed within unity. One cannot exist at the expense of the other. Both are equally essential. ${ }^{64}$

\section{Agustina Lumentut}

Agustina Lumentut (1937-2006) came from Central Sulawesi. She finished her pastoral studies at the INTIM Theological Seminary (STT INTIM) in Makassar and then was sent by her church, the Christian Church of Central Sulawesi (GKST) to study at Trinity College in Singapore. In 1959 she was ordained as a minister in Tentena. Her experiences in the ecumenical movement included being the Vice General Secretary of the PGI and member of the World Council of Churches' Standing Committee. ${ }^{65}$ Her presence at the leadership level of the PGI attested to the fact that women have been deeply involved in the ecumenical movement in Indonesia.

A summary of her views can be found in an article entitled, "Mau ke Mana Gerakan Keesaan di Indonesia?" (Where is the Movement toward

\footnotetext{
62 Ibid., 14-15.

63 J. L. Ch. Abineno, Pokok-pokok Penting dari Iman Kristen, (Jakarta: BPK Gunung Mulia, 1990), 189-204; J. L. Ch. Abineno, Apa Kata Alkitab, IV, (Jakarta: BPK Gunung Mulia, 1983), 5-11. Here he discussed what the Bible said about the congregation or the church.

64 Abineno, Gereja dan Keesaan Gereja, 15.

65 Her curriculum vitae can be found in Margaret Kirk, Agustina Wanita Masa Kini Mediator Pembangunan Pejuang Keadilan, (Jakarta: BPK Gunung Mulia), 2000.
} 
Unity Headed in Indonesia?). ${ }^{66}$ In this writing she indicates her concern about the churches which had joined the PGI. In her opinion they had not fulfilled their commitment to support togetherness or a sense of community under PGI coordination. This was evident in their unwillingness to carry out the decisions of the General Assembly and to contribute something to the cause of unity. ${ }^{67}$ As the sense of oneness and integration within the Indonesian society had weakened, so had their interest in unity too. The history of the Council and Communion of the Churches in Indonesia shows that spiritual union and organizational unity developed hand in hand with the ecumenical movement of the churches in Indonesia. These two forms of unity in fact did not need to contradict each other. Still, along the path to unity, Indonesian church leaders seemed inclined toward division. They considered the Communion of Churches to be important if they themselves were benefited by it. If they were not, they became indifferent.

Two things that did not need to conflict with each other or contradict each other in reality seemed to justify the divisive attitude of many church leaders. It was as though the important and meaningful thing was unity in fellowship in matters related to worship, visiting, and exchanging pulpits. If, however, it was something related to unity with the umbrella institution, such as membership in the PGI, they changed their tune. As long as our church is not asked to do a lot, we will execute the stipulations together; as long as it is not detrimental to our identity, we can tolerate the decisions of the General Assembly; as long as we play a managerial role at the national and regional levels, our church will support all programs without a reward, and so on. ${ }^{68}$

So, what was important to the churches in Indonesia was spiritual union. It was the spiritual union of churches that confessed Jesus Christ to be the head of the church, even though they felt that the PGI had always stressed both aspects of this union. Even though Calvin did not take church

\footnotetext{
66 A. Lumentut, "Mau ke Mana Gerakan Keesaan di Indonesia”, in Ferdy Suleeman, (ed.), Struggling in Hope, (Jakarta: BPK Gunung Mulia, 1999), 89-100.

67 Lumentut, "Mau ke Mana Gerakan Keesaan”, 91.

68 Ibid., 92.
} 
organization lightly, he felt that spiritual unity was very important. Church organization can differ according to the local situation. Yet if mutual recognition and acceptance existed within the one church as the realization of the brotherhood of the body of Christ, church unity would exist as well. So even though spiritual unity was stressed, it had to be expressed visually as well. Agustina's views were respected and rightfully so. To see the direction that churches in Indonesia were taking, she felt they needed to: a) fully experience unity and put it into practice; b) make their oneness visible and observable; c) manifest that unity as long as the church was in the world until the end of time. ${ }^{69} \mathrm{~A}$ perceptible unity in the life of the visible church is the concept we find in Calvin.

\section{Eka Darmaputera}

Eka Darmaputera (1942-2005), a Javanese of Chinese descent, was a pastor of the Indonesian Christian Church (GKI). He studied theology at the Jakarta Theological Seminary from 1960-1966. In 1977 he began his doctoral studies at Boston College, Boston, USA, and finished his degree in 1982 with a dissertation, entitled Pancasila - A Search for Identity and Modernity. He was his church's youngest Synod Chairman. Eka Darmaputera was active in the ecumenical movement and at one time served as chairperson of the PGI. ${ }^{70}$ As a theologian, he was a prolific writer. His writings can be found in a variety of books, journals and newspapers. One of his widely-known books on the ecumenical movement is Berbeda tapi Bersatu (Diverse but United), published in 1974. For our purposes here, his paper entitled "Penyatuan GKI, Keesaan Gereja dan Persatuan/Kesatuan Bangsa" (The Unification of the GKI, Church Unity, and National Unity/Integration) was used as a reference for throwing light on the cause of church unity in Indonesia. In this article he focused on the process of unifying three Indonesian Churches (the Indonesian Christian

\footnotetext{
69 Ibid., 99.

70 His curriculum vitae can be found in Ferdy Suleeman (ed.), Struggling in Hope, (Jakarta: BPK Gunung Mulia, 1999), 865-867.
} 
Church of West Java; the Indonesian Christian Church of Central Java, and the Indonesian Christian Church of East Java - all three originally mainly had a membership of Indonesians with a Chinese background) and its relationship to and interaction with church unity and national integration. At that time, just two years later in 1994, these three Indonesian Christian Churches told the General Assembly of the PGI in Jayapura that from that time on they would no longer be three churches but one, using the name Gereja Kristen Indonesia (GKI, Indonesian Christian Church). Eka had prefaced his article by expressing confusion. From the perspective of globalization, this GKI merger might just give rise to other excesses, namely the strengthening of primordial sentiments such as race, ethnic group and tribe. On the one hand globalization can indeed break down boundaries, but on the other it can create new barriers between people as well. In other words, this GKI merger could tear down old boundaries but at the same time create a new identity, a primordial identity. And this primordial tendency had threatened and was threatening national integration, the unity of the church, and the GKI itself.

I am not making it up if I say that the spirit of primordiality and sectarianism are ripping our national unity and integration apart, disabling the movement toward church unity, and casting a shadow over the unification of the GKI. ${ }^{71}$

In his assessment, even though Indonesia was a united country, it was being penetrated and permeated by compartmentalization based on religion, region and tribe. The same was true of the movement toward church unity in Indonesia. The PGI as the coordinating institution had become weighed down with bureaucracy and self-interest.

\footnotetext{
71 Eka Darmaputera, "Penyatuan GKI, Keesaan Gereja dan Kesatuan/Persatuan Bangsa”, in Hengky C. Widjaya (ed.), Jalan Menuju Keesaan, (Jakarta: BPK Gunung Mulia), 1996, 13.
} 
The Communion of Churches in Indonesia is no longer a movement but an organization, a division. It has become very bureaucratic. Within it the stench of self-interest has become very strong as well. ${ }^{72}$

This did not only exist in the PGI umbrella institution but in its member churches as well. Without realizing it, the sectarian spirit had already overwhelmed the churches in Indonesia. By saying this, Eka wanted to warn the churches in Indonesia that as they strove for unity they had to be careful of primordial and sectarian tendencies. I am reminded again of Calvin. Calvin stressed that church unity was also related to the sectarian tendency he faced at that time with the Anabaptists. He firmly insisted that sectarianism was the work of the devil and therefore had to be resisted. So, for Eka what was important for the future was to have a vision of the future. It was in that regard that he recommended that the Vision of Ecumenism and Vision of Nationalism become the Vision of the Indonesian Christian Church (GKI) in the future. ${ }^{73}$

\section{Concluding Remarks}

The seven figures discussed above have passed away. Yet they left a legacy of ideas and a spirit of ecumenism that are important for the churches of Indonesia. We may possibly meet up with similar figures in the future, but the degree to which their ideas will continue to inspire scholars and participants in the ecumenical movement in Indonesia at this time and in the future remains to be seen.

Roughly speaking, the first five figures were contemporaries. They lived and experienced the social and church life just before and after independence as well as the establishment of the DGI/PGI. Their life context was Indonesian nationalism that prioritized national unity and integration as well as the spirit of global ecumenism. It is not surprising, then, that their thinking was influenced by nationalism and ecumenical fervor. In fact,

72 Darmaputera, "Penyatuan GKI", 14.

73 Ibid, 18. 
nationalism was supportive of ecumenism. This is very discernable in Leimena who did not make a contrast between nationalism and church unity. He was aware that plurality was present in the society and in the churches of Indonesia. Church unity could stand above plurality. This kind of thinking is relevant to Indonesia's situation of today.

Meanwhile, with Rumambi we see that in order to create church unity, a cooperative coordinating institution was needed as a medium. Without organizing, church unity could not be expressed. Here we note that when Leimena emphasized the establishment of one church, Rumambi emphasized the need for one common coordinating institution for that purpose. Through that institution, the churches could witness together and develop a sense of oneness or solidarity and a sense of responsibility together. For Rumambi it is impossible for churches to walk together without being organized by a coordinating institution.

The seven theologians discussed above were influenced by their church backgrounds and the institutions of higher education where they studied. This, for example, is quite apparent with Soedarmo and Harun Hadiwijono. These two scholars of Systematic Theology served as educators at the Theological Seminary in Jakarta and at Duta Wacana Theological Seminary in Yogyakarta. They were obviously well-versed in Calvin because of that. Soedarmo's ideas on how to view church plurality with all of its variance were in line with Calvin's concepts. Therefore he developed the concept of unity in diversity. Unity in diversity would be realized if there were mutual recognition and acceptance. Meanwhile, Harun Hadiwijono considered the confession of faith to be the primary path to unity. A common confession of faith became the basis for organizational unity. Thus, he perceived that unity in faith was foremost. This view was consistent with Calvin and also dependent upon Calvin. Upon closer scrutiny it could be said that the two important documents within the Church Documents on Unity, that is the Pemahaman Bersama Iman Kristen (Statement on Mutual Profession (Understanding) about the Christian Faith in Indonesia), and 
Piagam Saling Mengakui dan Saling Menerima (the Charter of Mutual Recognition and Acceptance), actually contained the same idea.

Using Pokok-Pokok Tugas Panggilan Bersama (The Outline of Mission of the Common Calling) and the Charter of Mutual Recognition and Acceptance as a departure point, concrete evidence of unity would be visible only if churches carried out the stipulations of those two documents. From this perspective, it is interesting to consider Abineno's view that church unity must be evident in the visible church. We cannot talk about unity in a spiritual sense only - unity in Christ and that's it. With his colleagues, Abineno followed the ideas about which concrete form of unity was needed in Indonesia. Responding to the idea of SINOGI (Sinode Oikumene GerejaGereja Indonesia) in 1967, Abineno had pondered this and in 1983 stressed that, as the Bible testifies, both unity and diversity are essential. One cannot exist at the expense of the other.

In the next generation Agustina Lumentut and Eka Darmaputera followed the course of PGI during most of their lives. They were concerned about contemporary problems in the coordinating institution of the PGI which arose during the ecumenical movement. Lumentut, for example, was concerned about the lack of a spirit of togetherness that member churches had shown by not making decisions together. Darmaputera focused on the problem of uniting the three churches which had predominantly ChineseIndonesian membership. Both Lumentut and Darmaputera felt it was important to be wary of the public's tendency toward primordiality which could weaken their spirit of unity. It is important to listen to the reminders of these two figures because in reality church relationships could be disrupted by neglecting to carry out the decisions which had been made. Does being ecumenical not require a commitment to sacrifice one-sidedness? Does being strongly primordial not shut the door to others so that there is less space in which to live together? A critical question that could be posed in the current context is whether or not church unity is still dependent upon a united and integrated nation. Should the increased level of maturity of our 
churches mean instead that unity only needs to be based upon theological calling? 